\title{
Engineering Pedagogy Students Attitudes on Teaching Quality
}

\author{
Dana Dobrovská - Pavel Andres*
}

\begin{abstract}
The aim of the current survey was to make the outcomes of an analysis of mature-age student essays available in a convenient form to those who might be interested - engineering teachers and faculty management. Results of this survey are compared with a similar one conducted 8 years ago. Students presumed high expertise of their teachers, but also underlined importance of the real-world engineering examples.
\end{abstract}

Key words: teaching quality, essay analysis, qualitative methodology, teacher expertise, human/ didactic qualities.

\section{Introduction}

The higher education teacher's personality is a deciding factor of the quality of the educational process (Biggs, 2003; Mareš, 2013; Holeček, 2014). Experts in various sciences, such as theory of education, educational psychology, philosophy and sociology of instruction have tried to analyze this issue. Different approaches have been used: deduction - when scientists described an "ideal" teacher, induction - when students evaluated their teachers, or when psychological tests backed the illustration of real qualities of teachers. Sometimes, a combination of both approaches seemed appropriate (Koetsier et al., 1996).

Other authors offer lists of personality attributes - principles of effective teaching in higher education. Ramsden (2003) suggested 6 key principles:

- interest and explanation;

- $\quad$ respect for students and student learning;

- appropriate assessment and feedback;

- clear goals and intellectual challenge;

- independence, control (by students over their own learning) and

* Dana Dobrovská, Masaryk Institute of Advanced Studies, Czech Technical University in Prague, Czech Republic; dana.dobrovska@cvut.cz

Pavel Andres, Masaryk Institute of Advanced Studies, Czech Technical University in Prague, Czech Republic; pavel.andres@cvut.cz 


\title{
Acta Technologica Dubnicae \\ volume 6, 2016, issue 1
}

\author{
engagement; \\ - learning from students.
}

Other lists of desirable qualities of HE teachers are available from public bodies involved in professional recognition and accreditation. The UK Higher Education Academy (2010) defined these qualities partly in terms of core knowledge. Applicants via the individual entry route were expected to demonstrate knowledge of:

- the subject material that they will be teaching;

- appropriate methods for teaching and learning in the subject area and at the level of the academic programme;

- models of how students learn, both generically and in their subject;

- the use of learning technologies appropriate to the context in which they teach;

- methods for monitoring and evaluating their own teaching;

- the implication of quality assurance for practice.

\section{Survey I (2007)}

Some research activities on technical teacher personality were already undertaken at the Czech Technical University in Prague in past (Dobrovská, 1995; Šafránková, 2005). Other information on teaching quality has been regularly available to teachers from regular student questionnaire reports.

The aim of older survey was to make the outcomes of a students' essay analysis available to engineering lecturers and faculty management. Methodologically, we had found our inspiration in essay analyses as performed by Davies (2006) who had used this methodology at the University of Coventry.

Although the form of student essay has not had such a long tradition at Czech universities compared to the English speaking countries, we decided to replace regular student questionnaires. We knew students disliked to fill in questionnaires for research purposes, sometimes for unclear reasons.

This year, we decided to conduct similar survey and to make result comparison. We assumed moderate result differences due to the lapse of time and different respondents (differences in age and study experience).

Our research sample - students of the Master engineering programme (84 students, age $22-26,1 / 3$ from these were female) submitted their opinions and experience in a 500-1000 word essay "What makes a good engineering teacher". Perhaps as a result of word association, the word teacher in the title seems to have led the essay writers to concentrate on the role of lecturers and some more 


\section{Acta Technologica Dubnicae \\ volume 6, 2016, issue 1}

forms of class, generally a practical class, laboratory class, project tutor, etc. However, the students referred to the relationship between the teacher and the students' own learning.

The main attributes of a good engineering teacher were derived after 3 phases of qualitative evaluation (as performed by Davies). In the first phase all relevant semantic formations in essays were registered and assorted (substantives, adjectives and verbs). In the second phase synonyms were set aside and all the attributes were included in 3 categories:

- expertise of teachers;

- human qualities of teachers;

- didactic and presentation qualities of teachers.

In the last phase, quantification of answers and final classification of data was completed.

\section{$2.1 \quad$ Expertise}

A major agreement of students referred to expertise. A good engineering teacher has depth of knowledge and command of the study material, he/she keeps proper knowledge up-to-date and uses real-world engineering examples backed up by practical experience. One student wrote: “...it is all too easy to spot a teacher who has spent his whole life in education and merely conveys the bones of the subject matter without the flesh that real life would provide." The importance given to real-world examples and practical experience was significant because some professional engineering institutions are currently expressing concern over the declining numbers of new engineering lecturers with practical experience, caused by the pressure to appoint staff on the basis of research record. Surprisingly, students also mentioned a technical university teacher should have a good general education.

\section{$2.2 \quad$ Human qualities}

The student list of human qualities was rather long, even after a considerable semantic reduction: a teacher should be friendly, open-minded, communicative, tolerant, available and enthusiastic (the last component makes a teacher impressive and charismatic). Students criticized a teacher who only presents slides, without any interest in the audience, he/she should possess awareness and responsiveness to students' needs and should interact with students as individuals and in class. The teacher should also be human, objective, fairminded and honest. Among conative characteristics exactness, conscientiousness, patience, orderliness, responsibility and consistency were often mentioned. Most of the students who referred to these attributes did so in the context of seeking help with the subject. The teacher should be young in 


\section{Acta Technologica Dubnicae \\ volume 6, 2016, issue 1}

spirit and should be able to admit errors. His/her appearance should be tidy (!). Students also appreciated a sense of humour.

\section{$2.3 \quad$ Didactic and presentation qualities}

The students suggested a good engineering teacher should give sophisticated presentations. He/she should be a good speaker and speak with clarity, lectures should be well structured. Teachers should have a good knowledge of literary language (critique of poor Czech grammar, vocabulary and low semantic sensitivity is frequent..."some CTU teachers should be sent to an obligatory 2 semester course of the Czech language..."

If he/she can persuade an audience that the material is worthwhile and important then the listeners may well be inspired to improve the world around themselves with innovative and inspirational solutions. This needs for an excellent knack, for example and analogy, a feel for how the concept looks to a student who does not yet understand it and an instinct for how well the audience understood the last sentence spoken. A method of explanation that was instantly successful last year may only confuse this year's batch. These are clearly important and difficult skills. A good teacher is a great motivational tool for students; he/she should be creative and master a variety of adequate methods.

The students did not only describe the desirable qualities of good engineering teachers, but they were also thinking back on good teachers they met during their secondary school studies. "Good teachers are always fondly remembered and consequently the solid foundation that the students build with the help of the teacher is something that lasts for life". Another consideration... "a good teacher is one whose classes I am able to recall in years to come, not only when it comes to exams..."

\section{Survey II (2015)}

Similar methodology was used in a group of mature-age students (62 students, age 30-46, 1/4 female, students of Bachelor programme "practical classes teaching"). Again, 3 phases of evaluation were used: all relevant semantic formations in essays were assorted, synonyms were set aside and all the attributes were included in 3 categories: expertise of teachers, human qualities of teachers and didactic qualities of teachers.

\subsection{Expertise}

Similarly to previous survey, students expected good teachers to master their subject and give positive messages to students which are essential for motivation. "The most important quality an engineering lecturer can have is to be genuinely interested in the subject that they teach". "Enthusiasm is 


\section{Acta Technologica Dubnicae \\ volume 6, 2016, issue 1}

contagious and it encourages the student into further study of the subject, which in turn makes subsequent topics easier to understand" ... "the teacher is a knowing guide to the wanderer".

A teacher is able to impart technical knowledge and to foster the development of technical skills and should be able to manage rapidly growing knowledge base.

A well organized and suitably prepared lecturer is one likely to make a good impression on several respondents. "Preparation is vital to gain student confidence in their knowledge and the information they provide - no one likes to wait for a lecturer to work out his own slides".

\subsection{Human qualities}

Again, the student list of human qualities was rather long, even after a considerable semantic reduction. Two qualities which were mentioned in most essays were teaching enthusiasm and caring attitude toward students. The need for caring attitude was perceived as essential as many mature-age students were afraid of possible study failure due to long time lapse from high school study. Other qualities were similar to the ones which were described in previous research.

\subsection{Didactic and presentation qualities}

Text-books, notes and handouts provided by the lecturer rated very highly in the entrants' list of priorities, some favouring the fill in the gaps kind as a way of ensuring attendance at lectures, but all in agreement that clarity and quality are of the utmost importance.

Communication skills were also of vital importance to our essayists. The standards expected by them were high (and rightly so), as they did not just consider lecturing to be a one-way street. Interacting with the class or audience participation was cited in $25 \%$ of the essays as crucial to the success of the learning experience. A similar number of essays cited clarity of course structure as key to a lecturer's success.

\section{Comparison - Survey I and Survey II}

It was not considered appropriate to give precise percentages based on a low number of essays, and so the level of agreement was expressed as:

- strong agreement - referred to in virtually all the essays;

- good agreement - referred to in more than half essays;

- some agreement - referred in several essays. 


\section{Acta Technologica Dubnicae \\ volume 6, 2016, issue 1}

The specification of the attributes:

Strong agreement - virtually all the essays referred to these characteristics: that a good engineering lecturer: is enthusiastic, gives clear, well-structured presentations, uses real-world engineering examples backed up by industrial experience.

Good agreement - the following characteristics were clearly identified in more than half of the shortlisted essays: a good lecturer has a genuine interest in students as individuals and as members of an audience (is friendly, approachable and patient; is audience-aware and responds to feedback), strongly encourages learning, has depth of knowledge and command of the material, uses visual material and demonstrations effectively.

Some agreement - In addition to these characteristics, several essays indicated that a good engineering lecturer is good at simplifying difficult concepts and is well organized and reliable.

\section{Conclusions}

Similar results were received in the survey I and the survey II after essay analyses of two cohorts of students - despite of the lapse of time and differences in age and study experience. Students presumed high expertise of their teachers, but also underlined importance of the real-world engineering examples. Enthusiasm and ability to motivate were perceived as essential. In the second survey, the mature-age students indicated teacher support at the utmost importance.

\section{Acknowledgements}

This article was supported by the Fund of education policy of the Ministry of Education, Youth and Sports of the Czech Republic: Readiness of technically educated students for the teacher profession, management and motivation.

\section{References}

Biggs, J. (2003). Teaching for quality learning at university (2nd ed.). Society for Research into Higher Education and Open University Press.

Davies, J. (2006). What makes a good engineering lecturer? - students put their thoughts in writing. European Journal in Engineering Education, 3.

Dobrovská, D. (1995). How the Students Perceive their Studies II. In Ingenieurausbildung und Strukturveränderungen am Arbeitsplatz des ausgehenden 20. Jahrhunderts. Leuchtturm-Schriftenreihe (pp. 76-79).

Higher Education Academy: Individual Entry Route Application. Retrieved from https://www.heacademy.ac.uk/professional-recognition/awards/ national-teaching-fellowship-scheme-ntfs 


\section{Acta Technologica Dubnicae \\ volume 6, 2016, issue 1}

Holeček, V. (2015). Psychologie v učitelské praxi. Praha: Grada.

Koetsier, C.P., Wubbels, T., \& Korthagen, F. (1996). Partnership and Cooperation between the teacher education institute and the schools: A precognition for structured learning from praktice in school based programmes. In ATEE Conference. Glasgow.

Mareš, J. (2013). Pedagogická psychologie. Praha: Portál.

Ramsden, P. (2003). Learning to teach in higher education (2nd ed.). London: Routledge Falmer.

Šafránková, J. (2006). Názory studentů ČVUT v Praze na studium. Aula 14(4), 8-17. 